\title{
The impact of stakeholders on the implementation of water infrastructure projects at Umgeni Water
}

\author{
Lungi Makhaye and Cecile N. Gerwel Proches
}

\begin{abstract}
The engagement of stakeholders has become a key strategic area for Umgeni Water. Key statutory stakeholders, contracted or non-contracted, hold immense influence over, and have a great impact on, Umgeni Water's policy development and nature of work. Planning for stakeholder engagement can pose a challenge, particularly for the construction of water infrastructure projects, because relations between stakeholders are not static, but are rather dynamic and in a state of flux. In light of the project delays and financial setbacks that have been experienced while implementing infrastructure projects at Umgeni Water, it has become apparent that there are risks posed by the involvement and influence of key stakeholders. Umgeni Water thus needs to be proactive and put measures in place to ensure the successful implementation of projects. The purpose of this study was to provide a framework to assist management and teams working in the water infrastructure projects to better understand how to engage, manage and sustain successful relationships with stakeholders, in order to successfully implement water infrastructure projects. The engagement of stakeholders has become a key strategic area of focus for the successful implementation of water infrastructure projects. Effective stakeholder management can be achieved through gaining insight into and an understanding of the key stakeholders in terms of their identities, interests, influence and interactions. A literature review was undertaken to gain a better understanding of both the research approach and the problem area. The study was located within the qualitative research paradigm, and 15 in-depth, semi-structured interviews were conducted with the team that had been working on the project under study. The study identified the significant role played by the key stakeholders in the project and investigated the rules of engagement and effective communication approaches applied to ensure sustainability of the stakeholder relationship. It further identified contributing factors to the conflict experienced in the project's implementation. The findings indicated that there were missed opportunities for appropriate stakeholder management throughout the project, which encourages a new way of thinking, focusing on learning, and understanding the new business landscape. Organisations, as complex adaptive systems, are comprised of both internal and external agents. As stakeholders, these agents are different and dependent on each other in the sense that they constantly interact through feedback loops in order to improve performance and stay competitive. The implications are therefore that the focus should be on the relationships between stakeholders as systems, so as to carefully explore how a change in one system will affect another.
\end{abstract}

Keywords - stakeholder management, stakeholder engagement, water infrastructure projects, complexity, qualitative research

Lungi Makhaye and Cecile N. Gerwel Proches

Graduate School of Business and Leadership, University of KwaZulu-Natal

Durban, South Africa

Lungi Makhaye has over 17 years working experience in social facilitation with emphasis on community participation, stakeholder engagement and corporate social investment; these are also her research interests. She is currently working for Umgeni Water in Durban, South Africa, as a Social Development Coordinator. She holds a Master of Commerce in Leadership Studies (UKZN); Postgraduate Diploma in Leadership and Management (UKZN); Advanced Certificate in Organisational Development (UNISA) and a Bachelor of Public Administration (University of Zululand).

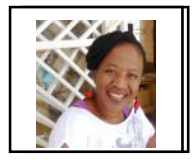

Dr Cecile Gerwel Proches is a senior lecturer in the Graduate School of Business and Leadership, University of KwaZulu-Natal, Durban, South Africa. Her research, supervisory and consulting interests include Leadership, Organisational Behaviour, Change Management, Training and Development, Systems Thinking, Complexity Theory, Action Research and Qualitative Research. Dr Gerwel Proches holds a PhD (Leadership Studies) (UKZN); MCom (Leadership Studies) (UKZN); BCom Hons (Industrial \& Organisational Psychology) (NMMU) and BCom (UPE)

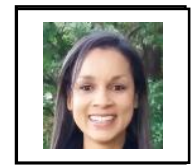

[...the focus should be on the relationships between stakeholders... 